\title{
Success, Gaps and Challenges of Power Sector Reform in Ethiopia
}

\section{Zelalem Girma}

Electrical and Computer Engineering Department, Arba Minch Institute of Technology, Arba Minch University, Arba Minch, Ethiopia

\author{
Email address: \\ zelalem.girma@amu.edu.et
}

\section{To cite this article:}

Zelalem Girma. Success, Gaps and Challenges of Power Sector Reform in Ethiopia. American Journal of Modern Energy.

Vol. 6, No. 1, 2020, pp. 33-42. doi: 10.11648/j.ajme.20200601.15

Received: September 5, 2019; Accepted: February 11, 2020; Published: February 18, 2020

\begin{abstract}
Ethiopia faces chronic power problems including insufficient generation capacity, low connectivity and poor reliability of transmission and distribution all of which constrain development. The Ethiopian power sector reform is necessitated by poor technical and financial performance of the power sector. The reform was initiated during 1997 just like any other Africa country due to deregulation of the power sector market in the world which aimed to increase the technical and financial performance of the sector. The government initiative to reform the power sector was backed by world bank by transforming Ethiopia Electric Light and Power Authority (EELPA) into Ethiopia Electric Corporation (EEPCO) in order to give the utility to work in business mind rather than as simple service sector. The main reason for powers sector reform is inability of state own vertically integrated utility to mobilize sufficient capital for the electricity sector development and expansion and waiting of federal government yearly allocated budget to perform its planned tasks. It is found that as most sub Saharan African countries including Ethiopia is in its initial steps of power sector reform even though there are some work done regarding corporatization, electricity amendment, management contract and tariff setting for independent power producers. The reform resulted in significant progress in connectivity and creating independent regulatory agency but failed to bring unbundling, encompassing independent power producers and improving transmission and distribution reliability. This article is based on country study by the author reviewing the status of power sector reform with special emphases on the success, gaps and challenges of the sector. The result of this study shows that power sector reform in Ethiopia has mixed result that gaps and challenges override the success due to weak institutional structure, weak project management and low skill capacity of human resources to implement the reform as intended, government inability to finance the reform process and the country still position itself at level-2 out of level-5 of maturity level of power sector reform.
\end{abstract}

Keywords: Power Sector Reform, EEPCO, Energy Policy, Ethiopia

\section{Introduction}

Ethiopia, found in east Africa with 1.1 million $\mathrm{km}^{2}$ area and a population of around 90 million, is endowed with enormous natural resources which help to generate electricity. Electric power was first introduced in Ethiopia in the late 19th century by installing the first diesel generator in the government palace light the palace. The first hydro power plant was constructed on Akaki River in the year 1912 in order to supply power to small factories, to the palace and to give light to a major road in the vicinity of the palace. In 1941 the first electric power utility called ' Shewa Electric power ' was established and later on the utility renamed as Ethiopia Electric Light and Power Authority (EELPA) in the year 1955 which was vertically integrated monopoly with a generation capacity of $35 \mathrm{GWh}$ and led by Board of Director appointed by government to engage in the business of generation, transmission, distribution and sale of electric energy to the public [1]. In order to accommodate the new change in the power sector environment around the world, the power sector reform, which was initiated by world bank have been implemented in 1997 by transforming and renaming EELPA into the Ethiopian Electric Power Corporation (EEPCO) by reorganizing its function on the basis of the principle of commercialization and decentralization for an indefinite duration.

In 2013 the EEPCO split into two separate utility namely Ethiopia electric power (EEP) which is responsible to Generation and transmission and Ethiopia Electric Utility 
(EEU) which is mandated to take care of distribution and sell of electricity. Currently EEU has a total generation capacity of 4290MW with total customer of around 2.5 million and aimed to generate 10,000 MW of Electric power in next few years [2]. While electrification programmes have improved access, many rural populations still remain deprived of electricity and $85 \%$ of Ethiopian population does not have access to electricity. The electricity access of the country is very low not exceeding 44\%(33\% grid connected plus $11 \%$ off grid) [3]. As most Africa countries, the gap between urban and rural access in Ethiopia is huge. Urban electricity access estimated at $80 \%$ while only $2 \%$ of the rural households have access to electricity $[4,5]$.

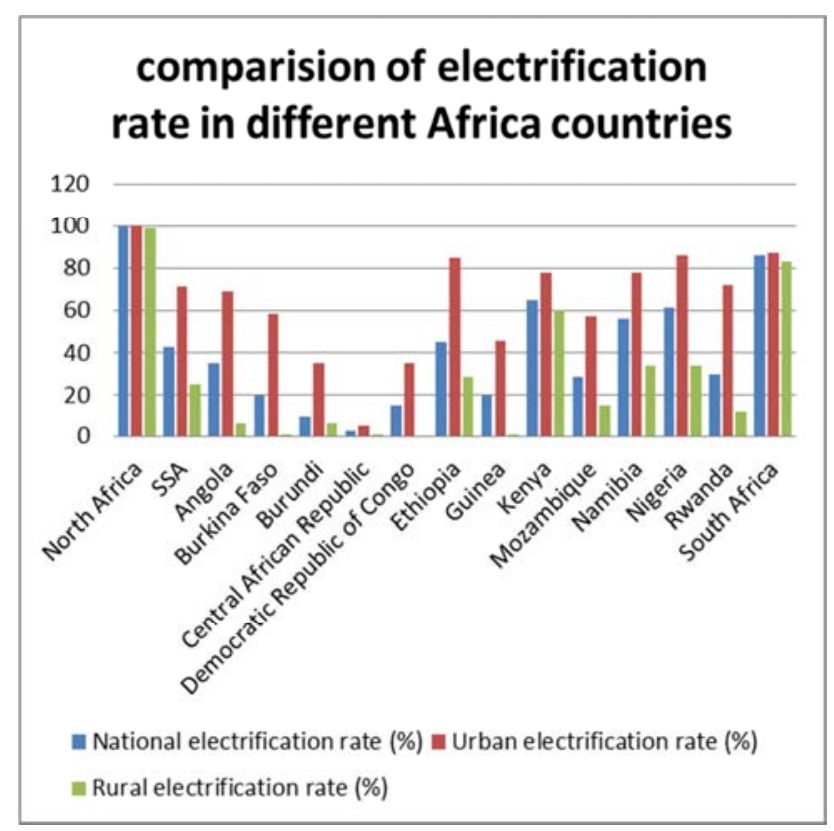

Figure 1. Electrification rate in different Africa countries [6].

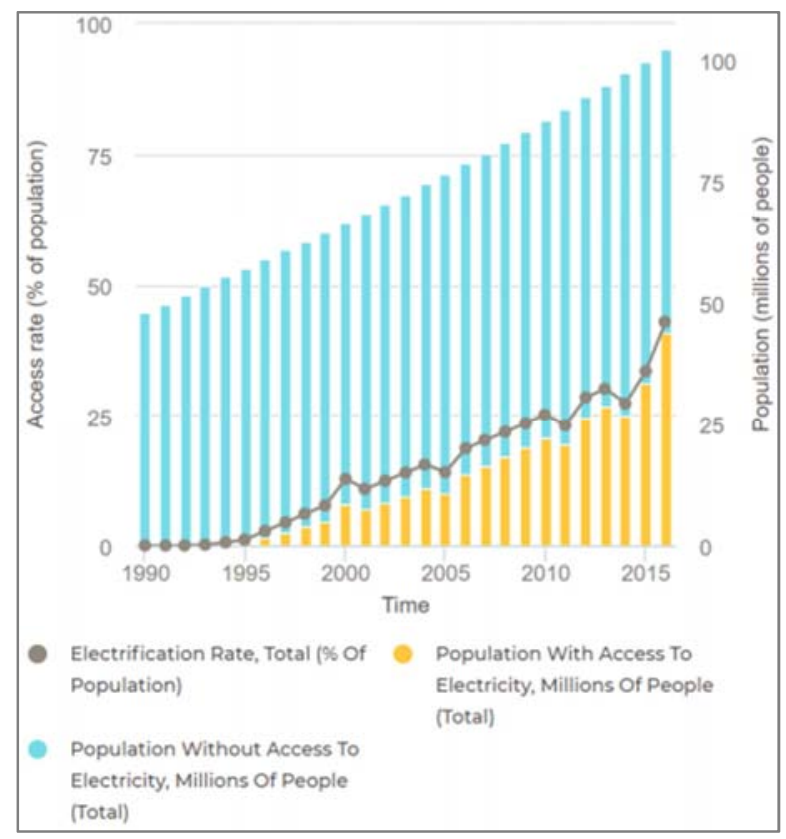

Figure 2. Access to electricity in Ethiopia, 1990-2016 [7].
Furthermore, the power sector has dominated by large hydropower plants $(80 \%)$ which are suffered by low power generation during dry season accompanied by poor transmission and distribution infrastructure. Around $6 \%$ of power come from thermal (standby diesel generation for peak loads) and the rest $8 \%$ is from renewable such as geothermal, wind and solar energy [8]. Since hydro dominated systems has been severely affected by drought, and the Government of Ethiopia is now diversifying the generation mix with other sources such as solar, wind and geothermal that will result in a more climate-resilient power system.

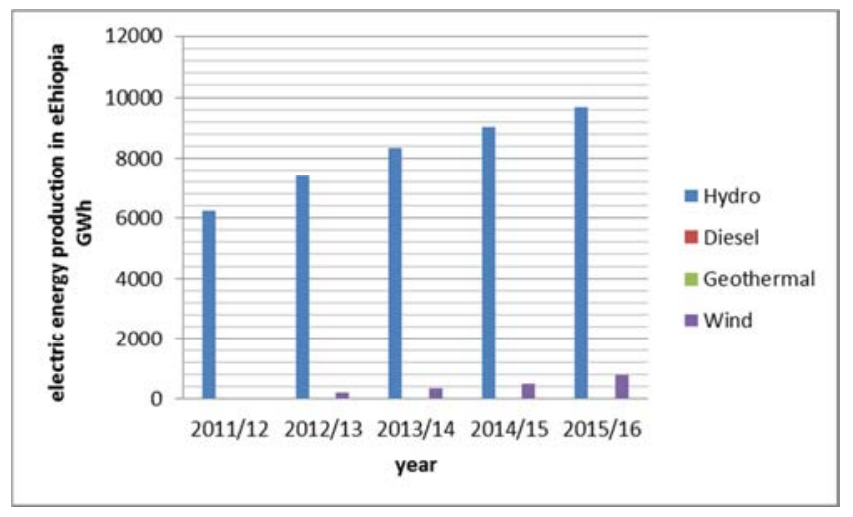

Figure 3. Energy production in Ethiopia GWh from different source [8].

As modern energy is a key component for economic development, poverty eradication and sustainable development, the low consumption of modern energy per capita hinder the country development and Ethiopia presently stands near the bottom end of the international development ladder, both in terms of very poor socio economic conditions and low scientific-technological advancements. The majority of population live-in rural area does not have enough access to modern energy such as electricity which leads to poor quality of life, under developed economy which resulted in high migration of rural youth to urban areas. The consumption of modern energy in the country is still very low in spite of the growth of respective national economies. This is demonstrated by very low levels of electricity consumption around $120 \mathrm{kWh}$ per capita.

\section{Performance of Ethiopian Power Sector}

The performance of the power sector in Ethiopia has generally been below expectations. In addition to low levels of access to electricity throughout the region, the sector is dogged by erratic and intermittent supply, low capacity utilization and availability, deficient maintenance and high transmission and distribution losses around 20\% among other problems [9].

The vertically integrated power utility is not commercially viable as they charge tariffs that are below costs in order to promote access to energy by the poor majority. As a result, the utility is not able to mobilize external capital for maintenance and expansion projects.

Due to high dependence of large hydro power whose 
generation output depend up on the availability of the water in the dam, the power sector faces huge power shortage during dry seasons which further aggravated by the global climate change. The construction of large hydro power also takes long time for commissioning, has social and environmental impact due to civil engineering work. Moreover, most of the country rivers where the hydro power based, are cross country rivers which needs mutual agreement between the downstream countries as seen from great renaissance dam constructed in Blue Nile river. For instance the Blue Nile River basin of the country shared mainly with Egypt and Sudan, The Omo River basin where four cascaded hydro power projects have been constructed is shared with Kenya. If not handled wisely the sharing of Single River with different countries leads to conflict of interest between upstream and downstream countries and sometimes can pave the way for regional conflict.

Ethiopia has faced serious problems in energy supply and utilization. The need to transform from traditional to modern energy sources demands heavy investment in terms of foreign currency and domestic resources. The continued destruction of forestry resources for firewood has resulted in environmental problems, loss of productivity and ecological imbalance. The increased scarcity and cost of household fuels particularly firewood, increased stress on women and children who usually are supposed to collect fuel. The low efficiency of energy utilization in all sectors and the cost of petroleum imports have brought worsening impact on Ethiopia's trade balance and foreign exchange availability.

The energy sector in Ethiopia composed of three main sub sectors; biomass, petroleum and electricity. $99 \%$ of the total energy supply comes from biomass sources whereas petroleum and electricity constitute the bulk of modern energy supply sources. Transport sector fully depends on modern energy source petroleum and petroleum is wholly imported and consumes a significant portion of total export earnings.

Annual per capita consumption of electricity is around $120 \mathrm{kWh}$ per year which is much lower than the sub-Sahara average $510 \mathrm{kWh}[10]$. The system loss in transmission and distribution line reaches $23 \%$ which is also higher than the world average $10-13 \%$ [11]. The high loss is partly due to poor maintenance on the transmission and distribution system.

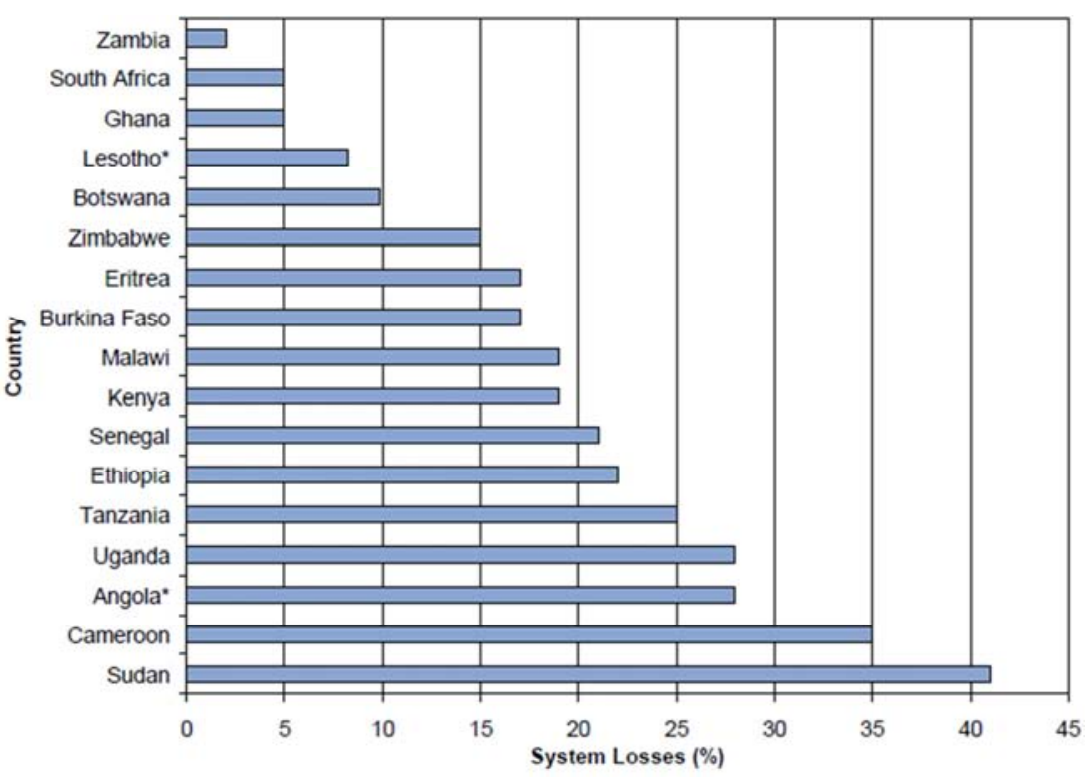

Figure 4. System Losses in Selected African Countries [11].

The country Electricity demand grows steady at $14 \%$ per annum which reflects the growing demand of electricity due to urbanization, economic and population growth. To meet the growing demand the government planned to generate $10,000 \mathrm{MW}$ of electricity in a period of growth and transformation (GTP -2010-2015) from hydropower, wind and geothermal sources. To alleviate shortage of foreign currency during construction of new power plants, the government planned to sale some portion of electricity generated to neighbouring countries Sudan, Djibouti and Kenya. The test transmission of $75 \mathrm{MW}$ and 100MW were started to Djibouti and Sudan respectively. The construction of high voltage Dc transmission line which has a capacity of 2000MW between Kenya and Ethiopia started on September $2013[12,13]$.



Figure 5. Current status of Electric Energy Development in Ethiopia [5]. 


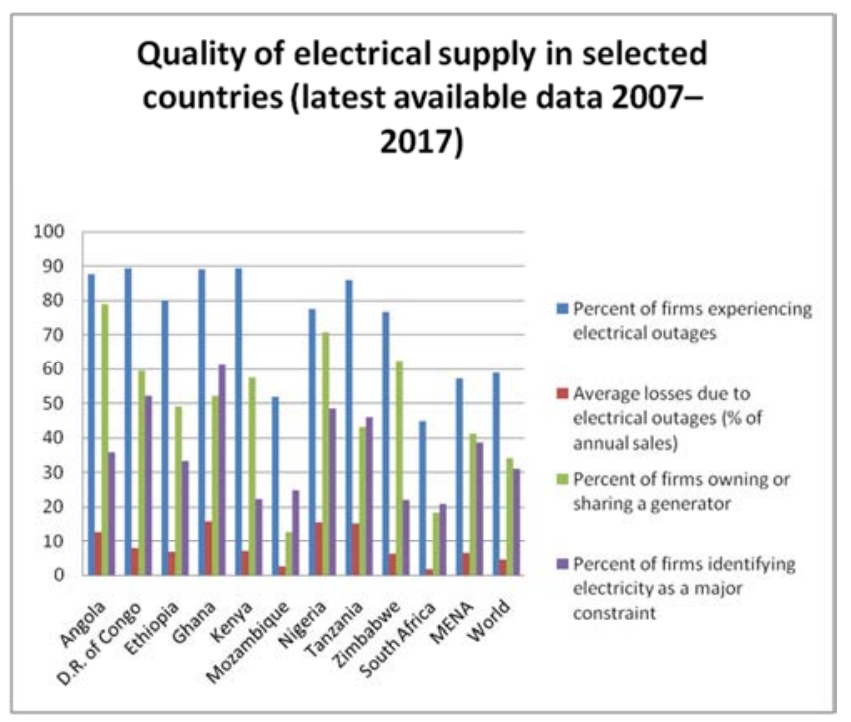

Figure 6. Qualityof electrical supply in selected Countries [14].

However, the country domestic consumption still under pressure with frequent power interruption and load shades due to insufficient generation during dry season and line overloading during peak hours. To assure power security in all seasons government started to construct a grid connected wind, solar photovoltaicand geothermal power in different sites of Ethiopia to complement hydro power source. The government also initiated biomass fuel development strategies to keep sustainability of these resources with a forestation and efficient use of it by using efficient cooking stoves. The bio-fuel use and development strategy also helps to blend diesel oil with ethanol and to reduce fossil fuel import and to save export earnings. The climate resilient green economy strategy enacted recently forces to generate all electric power from renewable energy sources. The energy policy directs to electrify remote rural areas with off grid technology such as solar PV, $\mathrm{min} /$ micro hydro power, small wind turbine and hybrid of them in the isolated mini grid form or standalone system such as SHS.

\section{The Ethiopian Energy Policy and Policy Result}

The rationale behind the need of energy policy in Ethiopia were to develop and utilize indigenous energy resources in the country so that to save the scarce foreign currency and to shield the economy from external and internal disruption of supply as well as price fluctuations; to modernize the energy development based on sound management practice and benign to the environment; to increase the efficiency of the energy sector and develop the necessary institutional and manpower capability to undertake energy development program. In general, the energy policy has three main objectives; to ensure reliable supply of energy at the right time and at an affordable price, gradual shift from traditional fuel usage to modern fuel usage, removal of bottlenecks in utilization of indigenous resource, self-sufficiency and increase energy efficiency To make country energy resources on the basis of overall development strategy priority accompanied by the introduction of energy conservation and efficiency

The followings were some of the mixed results that gained due to formulation of new energy policy;

Regarding the first objective -ensure reliable supply of energy at the right time and at an affordable price;

1. Very little improvement in traditional energy supplies such as biomass, the country still cover more than $90 \%$ of its energy demand from biomass after nearly 20 years of implementation of policy.

2. The country still depends on imported petroleum oil and very little improvement indigenous exploration of fossil fuel.

3. Great improvement in hydropower development. After injection of energy policy the hydro capacity increased from $521 \mathrm{MW}$ in 2001 to $2000 \mathrm{MW}$ in 2012 and expected to rise to $10,000 \mathrm{MW}$ in 2015 , therefore, the first objective is partially met.

Regarding the second objective - gradual shift from traditional fuel usage to modern fuel usage;

1. Electrification rate increased from $17 \%$ in 2006 to $46 \%$ in 2012 through grid extension but most coverage in urban and pre -urban areas and still majority of rural population are in darkness.

2. Very slow off grid electrification through the Rural Electrification Fund (REF). The reason for the slow rate compared to grid extension is that due to bureaucratic Fund release system and there is a gap between implementer and the fund giver.

3. In urban area there is a shift from biomass fuel for cooking to kerosene and electricity but no change in rural area; still use wood fuel for cooking. Very few people use biogas for lighting and cooking.

Regarding third objective -removal of bottlenecks in utilization of indigenous resource, self-sufficiency and increase energy efficiency;

1. Regarding traditional energy sourcebio-fuel; no selfsufficiency reached and the consumption of biomass fuel exceeds generation.

2. Regarding efficiency - Government in collaboration with different NGOs disseminated thousands of energy efficient cooking stoves throughout the country. However, still insufficient with regard to the size of the rural population and needs an innovative business model to sustain the supply.

3. Regarding IPP: In order to remove the bottleneck of investment law that prevents private investors to participate in power generation, investment law has been amended through proclamation No. 280/2002 which allows unlimited generation of electrical energy by foreign investors, which was restricted to $25 \mathrm{MW}$ in earlier investment law. However, there is no significant independent power producer IPP in the sector till now and needs measure and efforts to attract IPP in the sector. 
4. Regarding Bio-fuel- some company aggressively entered for production but slow down with unknown reasons.

5. Regarding petroleum - some local and foreign companies were entered a contract with government for exploration but no significant result yet shown.

6. Regarding renewable energy -import duties are lifted off for PV modules but still needs more conducive environment and incentives with clear implementation strategy and also have to incorporate other renewable sources such as wind and mini and micro hydropower.

7. regarding energy efficiency - some efficiency measures have been taken by government in the last two decades after injection of energy policy such as replacement of incandescent lamps with energy efficient CFL lamps with the help of world bank and subsequent banning of incandescent and halogen lamps from the market, dissemination of improved cooking stoves to rural /urban areas and the biogas and biofuel introduction in recent years. However, little progress has been shown in reducing transmission and distribution loses in electric line and still the losses are greater than the world average. In order to reduce the losses the old transmission and distribution line including associated transformers needs rehabilitation.

Regarding environment-the energy policy prioritizes large hydro power as the backbone of country electric generation. But large hydro powers are not yet environment friendly due to civil work which result in imbalance of the ecosystem, displaces the people round the dam and generate marsh gas (methane) due to decomposition of vegetation. Countrywide a forestation, improved cooking stoves and biofuel program aimed to blend biofuel with diesel for transport sector will reduce carbon dioxide emission. Currently undergoing public transport system (electric train) will further add its share in reducing greenhouse gas emission

\section{Power Sector Reform Models and Maturity Levels}

The main objective of power sector reform was to improve financial and technical efficiency of the power sector in developing country by introducing competition and private sector participation [15]. To implement the reform process international financial institutions (world bank) who were the sole funding source and initiator of the reform put standard power sector reform options flowed by the countries sequentially as much as possible;

a) Liberalization law:: which needs change of energy policy of the country and forces the country to enact laws to mandate the restructuring of the power sector.

b) Corporatization: commercializing state owned utility by removing the direct control of government.

c) Creating independent regulatory agency: creating independent regulatory agency or authority to set tariffs, issue licenses and control access to transmission network.

d) Independent power producer: Legalizing Independent Power Producers (IPPs) to contemplate private sector participation and allowing private investors to set up their own generation facilities even without comprehensive reform.

e) Unbundling: using vertical and horizontal separation of generation, transmission and distribution from natural monopolistic segment to introduce competition [16].

f) Privatization: privatizing all generation, transmission and distribution and limit political interference.

g) Actual reform program exhibit a variety of design particularly in market structure, on degree of private sector participation and sequence of reform stage based on circumstance of the country and its power sector. The variety of market structure can take different models [17].

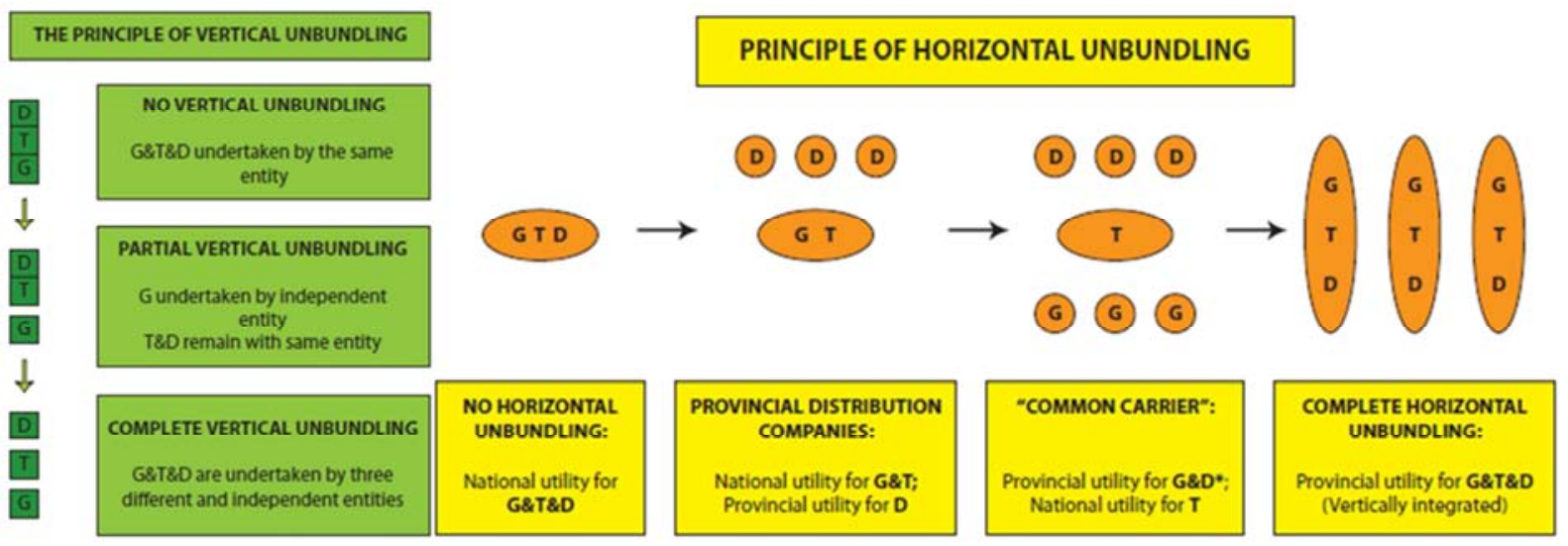

G: Generation; T: Transmission: D: Distribution.

Figure 7. Principle of vertical and horizontal unbundling [16].

1. Model-1: monopoly-no competition government owned vertically integrated utility; generation, transmission and distribution owned by government.

2. Model-2: single buyer -in this model government is a single buyer but independent power producers can generate and sale the electricity to government with negotiated long term tariff. Due to single buyer in the market negotiating power of IPP is very low. 
3. Model-3: whole sale completion - in this model distribution company can purchase electricity directly from generator they choose and get open access of transmission system to their service area.

4. Model -4: retail competition- allow all customer to choose their electricity supplier; open access for suppliers to transmission and distribution system.

To reach the required level of reforms the country power sector passes different maturity levels;

Level -1:

1. Power sector operated as government department.

2. High political interference.

3. The power sector work as service sector and few commercial freedom.

4. Very low tariff and high cross subsidy.

5. Very little institutional reform.

6. No separation of different part of business.

Level-2:

1. Power company distance from government-corporation.

2. Still political interference.

3. Little tariff increment and some subsidy.

4. Little institutional reform.

5. Minimal private sector participation.

Level-3:

1. Law passed accounting for full scale restructuring.

2. Vertical unbundling through accounting separation.

3. Setting up regulatory body.

4. Tariff reform.

5. Improvement in revenue collection.

6. Some private sector involvement.

Level-4:

1. Law passed for industry separation of generation, transmission and distribution.

2. Regulator setup cost reflective tariff.

3. Single byer model developed.

4. Substantial private sector participation in generation and distribution.

Level 5:

1. Business separated vertically into generation, transmission and distribution.

2. Independent regulator with full power to set cost reflective tariff.

3. Large scale private sector involvement.

4. Full competition in generation.

\section{Power Sector Reform Process in Ethiopia}

Power sector reform in Ethiopia starts with energy policy formulation in 1994 [18]. The comprehensive national energy policy formulated to ensure least-cost development consistent with the country's energy resource endowment and socioeconomic policies. The policy gives great attention to sustainable generation and utilization of Energy in all economic sectors. To implement the policy implementation strategies has been designed by targeting the most energy intensive economic sectors. As a result biomass development strategy, bio-fuels development and utilization strategy, Climate Resilient Green Economy (CRGE) strategy, the energy sector strategic plan (211-2015) and etc. was formulated and entered into action [19].

The reform process in Ethiopia was driven by the need to create enabling environment for an efficient and sustainable power sector. The reforms were initiated to improve operational, technical, financial performance and ultimately to attract private sector investments but have not yet yielded the expected results. Attracting private sector involvement has dominated the focus of power sector reform orientation, thereby prioritizing profit while neglecting the need to electrify rural areas and poorer urban neighborhoods.

The country power sector reform underwent in two phases; the first phases enter into implementation after issuance of the 1994 energy policy and proclamation No. 37/1996. The electric proclamation established the Ethiopia electricity agency (EEA) to regulate the power sector of the country in national level with objective to promote the development of efficient, reliable, high quality and economical electricity service. Regulation 18/1997 corporatized EELPA into EEPCO to run the electricity trading business on commercial principle i.e. to maximize profit. In the first phase of reform some foreign and national company showed interest to produce or generate power and to sell it to national grid but ended with absent of any meaningful private investment in power sector of the country. The first phase of reform also give due attention to rural electrification by setting independent rural electrification secretariat and allocating rural electrification fund. The fund available to viable projects and eligible private power producers on loan bases with incentives such as 5 year interest waiver and with low interest rate (soft loans).

The second phase of power sector reform started recently in 2013. As part of second reform phase the vertically integrated utility company EEPCO unbundled into two separate entities, Ethiopian Electric power (EEP) responsible for generation, transmission construction and operation and Ethiopia electric Utility (EEU) responsible for electricity distribution, network construction and operation and act as single buyer from independent power producer to sell back to consumers. It also mandated to import and export business of electric power and execution of cross country electricity trade. In this phase the government gave the management section of utility as managerial contract to Indian power Grid Company on two and half year management contract to introduce modern utility practice and to provide needed support during transition period. Furthermore the former Ethiopia electric agency renamed as Ethiopia Energy Authority (EEA) through Energy Proclamation number810/2013 published on January 27, 2014 to accommodate additional responsibility and uses rules, regulations, directives and standards to regulate energy efficiency, conservation, safety and quality.

The Energy authority also responsible for negotiation of tariff for fully off-grid independent power projects (IPPs). The new EEA covers the electricity as well as energy 
efficiency activities and is authorized issue and renew license to operators on all segments of electricity operation, generation, transmission, distribution, sales, exports and imports. However, still EEA and EEU are government owned enterprises accountable to the Ministry of Water, irrigation and electricity. The objective of these restructuring was to create modern entities capable of providing efficient, reliable and quality services. Another step has been taken to encourage private power producer (IPP) in power sector development in the second phase. The generation limit from each source of energy clearly set and the feed in tariff ratified but open to negotiation. The feed in tariff fixed by the board of director of Ethiopian energy Authority (EEA) and approved by the Ministry of water, irrigation and electricity.
Some of EEA mandates are determine quality and standards of electricity services, issue license; generation, transmission, distribution sales, import/export, recommend tariff, issue professional competency certificate. The rural electrification remain under EEP as government provide a direct capital subsidy to the Universal access program and EEP retain the responsibility of constructing the rural distribution network [2].

Both the first and second phase of the reform maintains the single buyer model as means to facilitate IPP investment opportunity and to minimize the market risk. The government have been loath to fully privatize the power utility believing that national utility continue to play a crucial role in country development.

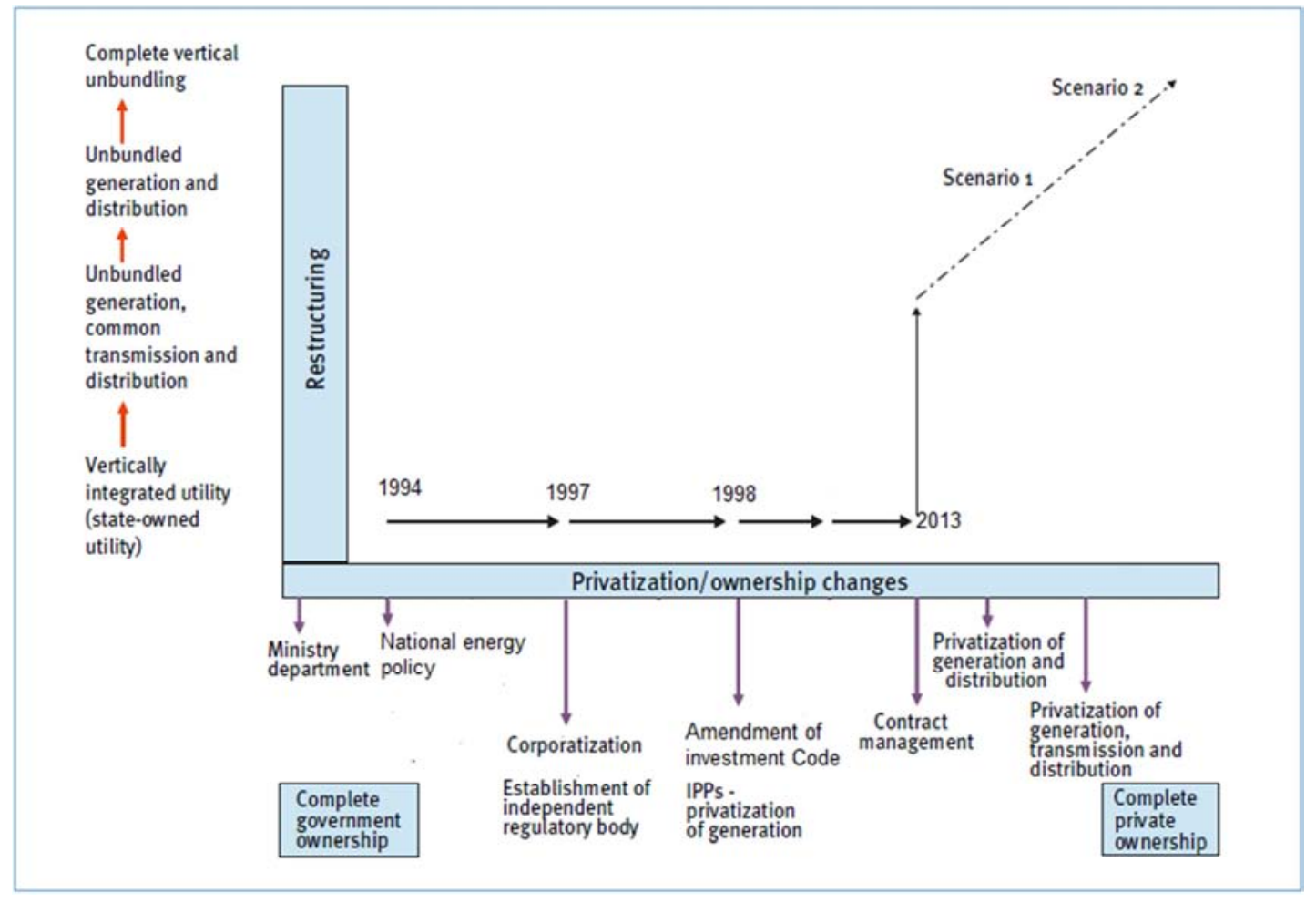

Source: adopted from [9].

Figure 8. Possible road map of Ethiopian power sector reform.

Scenario 1 and 2 possible future reform and possible extreme options.

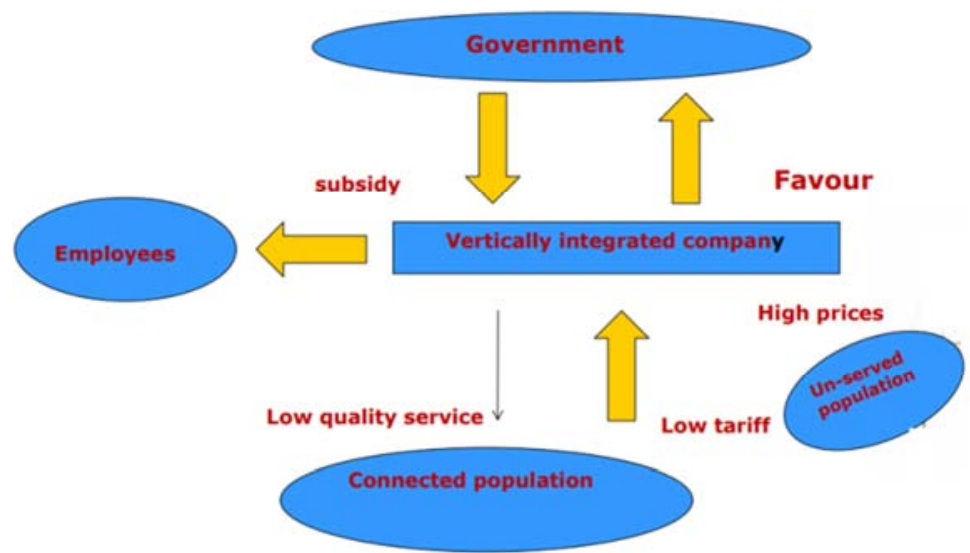

Figure 9. Overview of Ethiopian electricity sub sector old utility model [20]. 


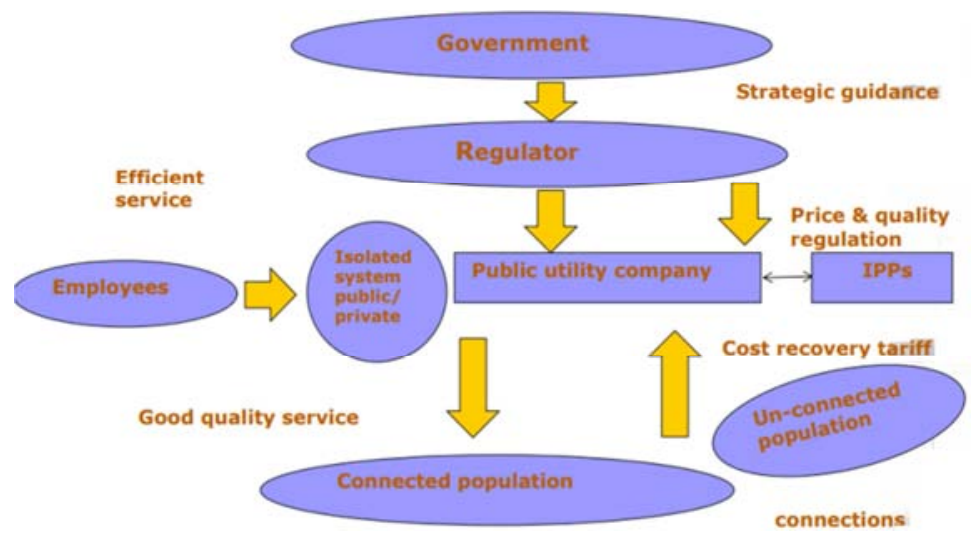

Figure 10. Overview of Ethiopian electricity sub sector New utility model [20].

Table 1. Power generation addition after power sector reform [4].

\begin{tabular}{lll}
\hline Generation & Capacity (MW) & Year \\
\hline Tekeze & 300 & 2009 \\
Beles & 400 & 2010 \\
Tis Abay II & 73 & 2001 \\
GilgelGib I & 184 & 2004 \\
Gilgel Gibe II & 420 & 2009 \\
Gilgel Gibe III & 1870 & 2015 \\
AshogodaWind power & 42 & 2013 \\
AdamaIWind power & 51 & 2012 \\
AdamaIIWind power & 153 & 2015 \\
\hline
\end{tabular}

\subsection{The Need of Power Sector Reform}

Ethiopia has faced a number of serious problems relating to poor commercial and technical performances in the sector which is reflected in the nation's poor electricity development and quality. Furthermore, the power utilities in the country have enjoyed a monopolistic hold over EELPA at the time of reform and the power sector was characterized by, unreliability of power supply, low capacity utilization and availability factor, poor maintenance; poor procurement of spare parts, high transmission and distribution losses, unsatisfactory financial performance, high dependence of the sector on government budget due to very low tariff and in adequate quality and coverage. The inability of EELPA to mobilize sufficient investment capital for the electricity sector development and expansion is an important reason for the embarking on comprehensive reforms in power sector. Thus main objective of power sector reform was to improve the financial and technical performance of the National power sector and to promote social and economic development.

The power sector reform believed to bring transparent regulatory mechanisms thereby creating a more conducive investment climate for the power sector which led to investment in additional generating capacity and to bringing the energy issues firmly onto national agendas and priorities. Therefore, the purpose of the reforms was to restructure state monopolies in to competitive entities via vertical and horizontal unbundling and a significant contribution by the private sector. By definition power sector reform is restructuring of public utility; corporatization and commercialization of utility operations; establishment of the legal and regulatory framework, setting a level playing field for all operators in the power sector; privatization of existing public utility assists; and, private sector investment in power projects [19].

\subsection{Drivers of Power Sector Reform in Ethiopia}

1. Unreliability of power supply.

2. Low capacity utilization and availability factor.

3. Poor maintenance and procurement practice.

4. High transmission and distribution losses.

5. Poor technical and financial efficiency.

\subsection{Identified Gaps of Power Sector Reform in Ethiopia}

1. Not attractive for IPP: The setup makes it less attractive for private investors given the influence the government has over the sector. The government prices their tariffs based on what the low income group can afford to pay and therefore there is usually no case for large financially viable projects invested by IPP. The selling price of electricity is set by the regulators at a tariff of only about USD 0.06. A government policy dictates the need to keep these tariffs at this level to ensure that low income families have access to electricity. In recent time there is improvement in the tariff but still it is not cost reflective.

2. Single Buyer of electricity: Because the utilities are the Single Buyer of electricity they have the sole bargaining power when it comes to negotiating long term power purchase agreement (PPA's).

3. Conflict of interest: There is an inevitable conflict of interest arising from a single entity being the generation company as well as the buyer when the IPP tries to trade the electric power according to FIT.

4. Monopoly of transmission and distribution line: The transmission or distribution system operator needs to be unbundled and regulation has to dictate their tariffs and rules of operation.

5. Power sector reforms in Ethiopia have not yet met the expected objectives. The sector has not been able to attract the investment capital needed and private sector investment and the bulk of the investment is guaranteed 
by the government. This is contrary to the expectation that government would be freed of financial responsibility.

\subsection{Success of Power Sector Reform}

1. Regulatory and operation functions are separated.

2. Re-establishment of utility as business corporation aimed at maximizing profit.

3. Feed in tariff enacted.

4. Some Private power producer enter into generation of power (eg 1000MW Corbatti geothermal power plant by USA based Power Africa company).

5. Service standard and regulatory obligations are defined.

6. Operational improvement have been noticed in some area such as end user connection (from 800,000 in 2006 to 2.5 million in 2015) Increment in annual generation from around 400MW in 1994 to around 4290MW in 2016 and 10,000 MW in near future.

7. Some demand side management and energy efficiency program launched and mandated to new Ethiopia energy Authority.

8. The country revised two times its national electrification program (NEP), NEP 1 in 2017 and NEP 2 in 2019. In NEP 2 Ethiopia desires to electrify $100 \%$ its rural and urban area in 2025 and set cost reflective tariffs, significant improvement in billing and collection rates and decentralization of the utility to regional constituencies [21].

\subsection{Challenges of Power Sector Reform in Ethiopia}

1. Financing the generation side: power generation require huge capital investment and the large hydropower which was dominant in Ethiopia, not well supported by international financing organization such as world bank and IMF. This creates a challenge to secure funds to expand the generation base. Due to huge capital requirement and lack of guarantee private sectors are not participated in the generation side even if the policy allowed them to participate.

2. High costs of supplying rural and peri-urban households.

3. Population growth.

4. Electricity demand growth.

5. Persistent poverty.

6. Debt and deficits.

\section{Recommendation on Power Sector Reform}

1. Neither corporatization nor commercialization will produce the expected results without the right kind of management in charge. Therefore great attention should be given to build managerial capacity of the utility.

2. Reform by definition aimed at transforming the typical government-owned monopoly utilities to a standard model characterized by vertical and horizontal unbundling of generation, transmission and distribution, dominated by private participants, and organized around competition in an independently regulated environment. However in Ethiopia after decade of reform the utility is still under monopoly of government and this will have to be changed in the future.

3. Attracting the private sector has proved difficult, largely due to the low levels of infra structural development and customer base. Therefore, innovative financing scheme and smart subsidies still needed to attract private IPP.

4. The independent regulatory body should be distanced from the government and insulated against political, corporate and other pressures.

5. To work in harmony the two EEPCO utility (EEP and EEU) establishment of common standard are necessary to work in coordination between the two.

6. Larger disparity between energy production and effective use of energy has been seen in the country. Therefore stringent efficiency measures has to be taken in the future

7. In order to cover debt obligation during power generation and transmission, the current low electricity tariff $(\$ 0.03 / \mathrm{kWh})$ has to be raised to significant level and the tariff has to be revised based on country currency devaluation [22].

8. The institutional arrangement of power sector have to be restructure and has to give more autonomy and power to regional and Zone bureau in order to electrify rural area by using modular off grid technologies.

\section{Conclusion}

In this paper, the success, gaps and challenges of Ethiopian power sector reform has been investigated. Overall, the outcome of reform has been mixed, and all expected achievements have not always materialized. The reform promised to bring overall improvements in the sector, including better management, decreases in technical and other losses, better availability of electricity, job creation and economic growth. However, the power sector reform in Ethiopia mainly corporatized the utilities and invited IPPs to offset the generation shortfall experienced by the state-owned utilities and there is much slower progress with respect to reforms aimed at minimizing or withdrawing government control of the power sector. After a decade of reform still the power utility is monopolized by the government and has not solved the above aforementioned problems in the power sector of the country. Almost $99 \%$ of rural people do not have access to electricity and continue using traditional energy resource biomass for cooking, heating and lighting purposes. The urban population use biomass and petroleum oil for cooking and all transport sectors depends upon imported oil. The increase of demand and price of imported oil resulted in accelerated climate change and global warming. Therefore, immediate revision of power sector reform and power sector master plan needed in order to address the challenges in the sector and considerable improvement has to be made based on the lesson learnt from previous reform. The revised 
reform must give due attention to the protection of the environment, the expansion of energy infrastructure, firm security of supply, diversification of sources, awareness creation of energy conservation at consumer side and accessibility of all sectors of the population with special attention to rural population.

\section{References}

[1] Ethiopian electric power corporation http://www.eepco.gov.et/corporationhistory.phpaccessed on Jan26, 2018.

[2] Ethiopia electric power http://www.eep.gov.et/accessed on Jan20, 2018.

[3] Ethiopia Geothermal Sector Development Project, world bankhttp://wwwcif.climateinvestmentfunds.org/sites/default/fi les/Ethiopia\%20GSDP\%20_\%20PAD_4102014\%20.pdfacces sed on Sept2, 2018.

[4] Lighting Africawww.lightingafrica.org/wpcontent/uploads/2016/07/Ethiopia-Market-IntelligenceReport_June2013.pdfaccessed on March 12, 2019.

[5] ShiferawTelila Ethiopian power sector Progress briefing Washington DC, 2019 https://www.usea.org/sites/default/files/event/Ethiopian\%20Po wer\%20Sector\%20Progress.pdf accessed on Sept 2019.

[6] IEA, World Energy Statistics, 2017 and World Bank, World Development Indicator database, https://www.iea.org/dataand-statisticsaccessed on November 2019.

[7] Energy progress report ESMAPhttps://trackingsdg7.esmap.org/country/ethiopiaaccess ed on Jun 2019.

[8] Investment Brief for the Energy Sector in Ethiopia, power Africa,

https://www.usaid.gov/sites/default/files/documents/1860/Ethi opia_IG_2015_05_03.pdfaccessed on August 10, 2019.

[9] StephenKarekezi and WaeniKithyoma Renewable Energy in Africa: Prospects and Limits, AFREPREN (2003) https://sustainabledevelopment.un.org/content/documents/nep adkarekezi.pdfaccessed on Oct 25, 2019.

[10] Ethiopia Investment Plan https://www.oecd.org/env/cc/TADELE_FDRE\%20Ethiopia\% 20Scaling\%20-

\%20Up\%20Renewable\%20Energy\%20Program\%202012.pdf Accessed on Feb29, 2018.
[11] Scaling - Up Renewable Energy ProgramEthiopia - Electric power transmission and distribution losses https://tradingeconomics.com/ethiopia/electric-powertransmission-and-distribution-losses-percent-of-output-wbdata.htmlaccessed on Jun 23, 2019.

[12] Ethiopia begins test running power supply to Sudanhttp://www.tigraionline.com/articles/article120815.html accessed on April 13, 2018.

[13] Ethiopia-Kenya power systems interconnection project revision of environmental and social impact assessment and resettlement action plan studieshttp://www.afdb.org/fileadmin/uploads/afdb/Document s/Environmental-and-Social-

Assessments/Ethiopia\%20RAP\%20Final\%20Report.pdfaccess ed on July 28, 2019.

[14] Manfred. H, Simon. T and Lucia. D Energy in Africa: challenge and Opportunity, Springer Brief in Energyhttps://link.springer.com/content/pdf/10.1007\%2F9783-319-92219-5.pdf.

[15] Ioannis N. Kessides, "The impacts of electricity sector reforms in developing countries," Electr. J. 25 (6) (2012) 79 88.

[16] The reform of the power sector in Africahttp://africatoolkit.reeep.org/modules/Module4.pdfAccessedon Jan 2020.

[17] Katharine. Nand Anton. E,'Demise of the standard model for power sector reform and the emergence of hybrid power markets, "Energy Policy 36 (2008) 3948-3960.

[18] MengistuTeferra,"Power sector reforms in Ethiopia: options for promoting local investments in rural electrification,"Energy Policy 30 (2002) 967-975.

[19] BekeleBayissa“A review of Ethiopian Energy policy and Biofuel strategy "Digest of Ethiopia's National policies, strategies and program 2008.

[20] Getahun Moges, electricity sector regulation, Ethiopia https://www.esi-africa.com/wpcontent/uploads/Ethiopia\%20electric\%20power\%20regulation \%20presentation\%20final.pdfAccessed on Sept 2019.

[21] National Electrification Program 2.0 Integrated Planning for Universal Accesshttps://minigrids.org/wpcontent/uploads/2019/04/Ethiopia-2.0.pdf Access Feb 6,2020.

[22] Baseem. K and Pawan. S, "The Current and Future States of Ethiopia's Energy Sector and Potential for Green Energy: A Comprehensive Study," International Journal of Engineering Research in Africa 33: 115-139. 